\author{
Wioletta Leszczyńska \\ Technik budownictwa, Studentka \\ Politechniki Gdańskiej \\ Wydział Inżynierii Lądowej I Środowiska \\ s177696@student.pg.edu.pl

\section{Marek Pszczoła} \\ Dr hab. inż. Marek Pszczoła, prof. PG \\ Katedra Inżynierii Drogowej i Transportowej \\ Wydział Inżynierii Lądowej i Środowiska \\ marek.pszczola@pg.edu.pl
}

DOI: 10.35117/A_ENG_21_04_02

\title{
Analysis of equivalent temperature to design of asphalt pavements in Poland using the AASHTO 2004 method
}

\begin{abstract}
The paper presents the analysis of the equivalent temperature on the basis of the fatigue cracking criterion of asphalt layers according to the AASHTO 2004 method and the structural deformation of subgrade criterion according to the Asphalt Institute procedure. The calculations were made with application of the KR5 pavement structure and temperature data obtained from 50 meteorological stations and from the period of 30 years from 1989 to 2019, provided by the Institute of Meteorology and Water Management. The influence of variable traffic with heavy vehicle traffic was taken into consideration, both during the day and throughout the year. It was presented how the values of the equivalent temperature change in the territory of Poland depending on the location of the meteorological station. The computational analysis showed the variability of the equivalent temperature on the territory of Poland in the range from $14.68^{\circ} \mathrm{C}$ (Suwalki) to $16.99^{\circ} \mathrm{C}$ (Tarnow). The weighted mean value of the equivalent temperature for the entire year is $16.01{ }^{\circ} \mathrm{C}$ and it is higher than the value adopted in the catalogue of typical flexible and semi-rigid structures that is equal to $13,00^{\circ} \mathrm{C}$. The change in the equivalent temperature value on the designed thickness of asphalt layers of the pavement structure has been also assessed in the paper.
\end{abstract}

Keywords: Pavement design; Equivalent temperature; Fatigue life; AASHTO 2004 method

\section{Introduction}

The changing climate and the increased traffic load of heavy vehicles increase the damage to road surfaces. To meet this problem, fatigue models are developed in Poland and around the world to calculate the fatigue life of the pavement, and thus it becomes necessary to determine and update the equivalent temperature to the design of road pavement structures. The term equivalent temperature should be understood as a constant temperature value at which the fatigue damage to the pavement at this temperature is equal to the sum of fatigue damage that occurs during the year during changing temperature conditions under the assumed road traffic load.

The method of determining the equivalent temperature in Polish climatic conditions, taking into account the fatigue tests, was presented by D. Sybilski and W. Bańkowski in the article [8]. In the book [2], which is a summary of the research program as a result of which the new Polish catalog was developed [9], the team led by J. Judycki analyzed the equivalent temperature using the fatigue criteria of the Asphalt Institute, the Shell method, the French method, as well as taking into account the variable modules elasticity of the subsoil. The 
analysis of the fatigue life needed to determine the equivalent temperature based on the French criterion and the Asphalt Institute criterion concerning the heavy vehicle traffic load was presented by M. Spławińska and P. Zieliński in the article [7]. These considerations suggest the appropriate selection of the criterion for a given type of pavement and the unification of the value of the equivalent temperature.

The AASHTO 2004 method [1] was developed as part of the American research program National Cooperative Highway Research Program based on research conducted on experimental sections, on the basis of which fatigue models were developed, described in detail by J. Judycki in articles [3, 4]. However, in the works carried out at the catalog preparation stage, the AASHTO 2004 method was not fully applied to determine the value of the equivalent temperature. At that time, they were used, inter alia, Asphalt Institute methods, French method, and Shell method. Equivalent temperature analyzes were carried out in the first stage of works when the AASHTO 2004 method was not yet adopted as the basic method of fatigue life calculation.

This article aims to present the analysis of the equivalent temperature variability in Poland based on the latest temperature data and its impact on the thickness of the designed asphalt layers of pavement structures based on the fatigue cracking criterion of asphalt layers from the AASHTO 2004 method and the criterion of structural deformation of the subsoil according to the Asphalt Institute.

\section{Analysis of air temperature data and determination of pavement temperature}

For further analysis of the equivalent temperature, the meteorological data provided by the Institute of Meteorology and Water Management for 30 years, from 1 January 1989 to 31 December 2019, were used. In relation to the temperature data adopted to determine the equivalent temperature in the current catalog [9] (period from 1 January 1981 to December $31,2010)$, these data included the most recent available temperature measurement period in Poland. The received data came from meteorological stations evenly located throughout the territory of Poland. At the initial stage of the analysis, meteorological stations with data discontinuities caused by interruptions in registration or located in areas with limited road access (e.g. mountain peaks) were excluded. Ultimately, 50 meteorological stations with complete air temperature measurement data were selected for further analysis. A summary of the location of meteorological stations and the results of average air temperature values for 30 years are presented in Figure 1. The distribution of isolines was developed in a graphic program using linear interpolation. The difference in temperature between adjacent locations of meteorological stations and the distance between them was taken into account. 


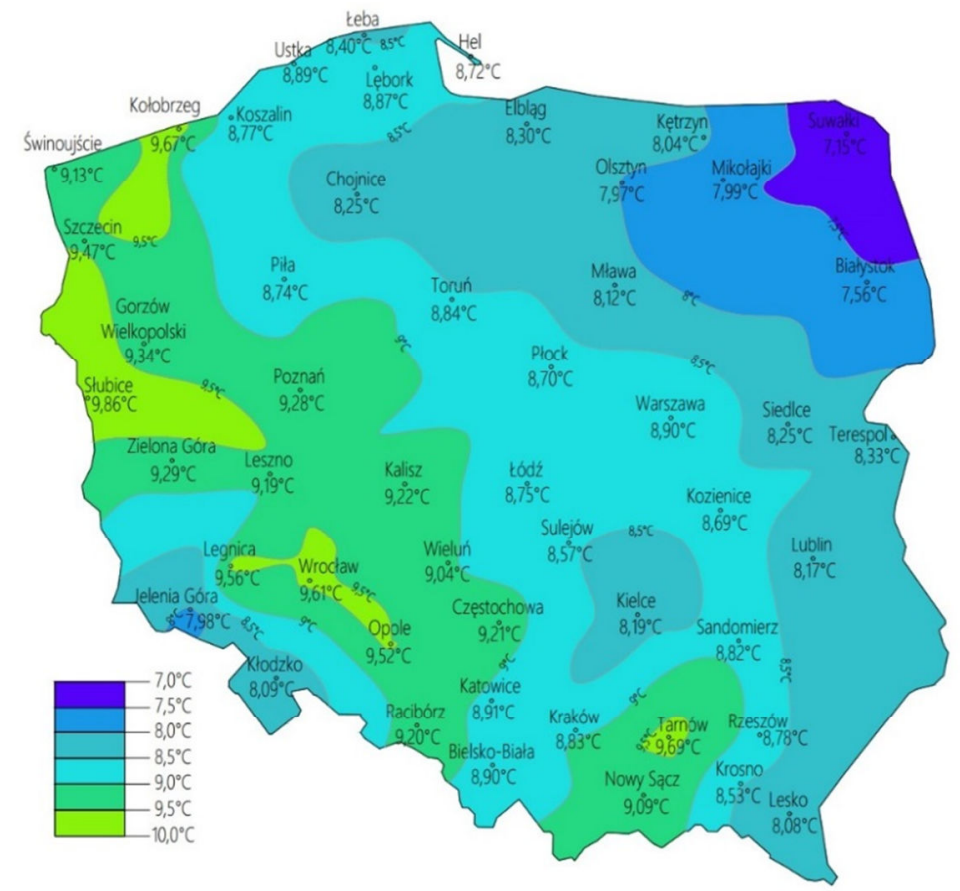

1. Locations of meteorological stations and average air temperature values from the period of 30 years $(1989$ - 2019)

To determine the average monthly pavement temperature used for subsequent analyzes of the equivalent temperature, the pavement structure representative for the KR5 traffic category, type A1 from the catalog was adopted as representative [9].

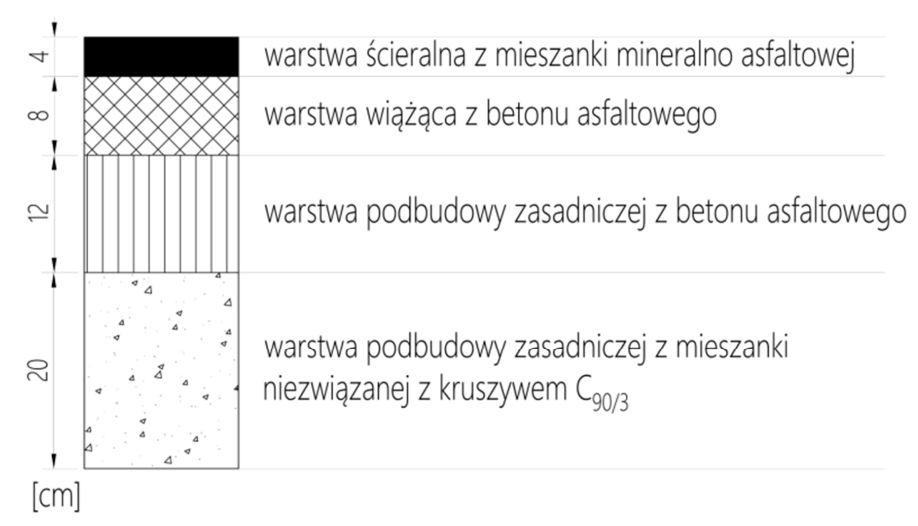

2. Pavement construction for the KR5 traffic category [9]

The temperature in the pavement was determined as the average monthly value of the temperature at a depth of $1 / 3$ of the thickness of the asphalt layers following the relation (1) also used in the book [2] and the article [8]. This dependence was also used in the procedure of determining the equivalent temperature adopted for the preparation of the catalog [9].

where:

$$
\mathrm{T}_{\mathrm{s}}=\mathrm{T}_{\mathrm{s}, \mathrm{p}}\left(1+\frac{1}{\mathrm{z}+4}\right)-\frac{34}{\mathrm{z}+4}+6
$$

$\mathrm{T}_{\mathrm{S}}$ - monthly average surface temperature $\left[{ }^{\circ} \mathrm{C}\right]$,

$\mathrm{T}_{\mathrm{s}, \mathrm{p}}$ - monthly average air temperature $\left[{ }^{\circ} \mathrm{C}\right]$,

$\mathrm{z}$ - depth in asphalt layers at which the pavement temperature is determined, measured from the pavement surface [inches] [2]. 
In order to take into account the daily load distribution of heavy vehicles traffic in the analysis of the daily pavement load more precisely, the pavement temperature was calculated using the weighted average monthly air temperature values. Based on the results of the General Traffic Measurement [5, 6] carried out in 2015 by the General Directorate for National Roads and Motorways, it appears that heavy vehicle traffic takes place mainly during the day from 6:00 a.m. to 10:00 p.m. (Fig. 3). Therefore, for further analysis of the equivalent temperature, the following weight division was adopted: 0.7 for the values of temperatures during the day (from 6:00 a.m. to 10:00 p.m.) and 0.3 for the temperatures during the night (from 10:00 p.m. to $6: 00$ a.m.).

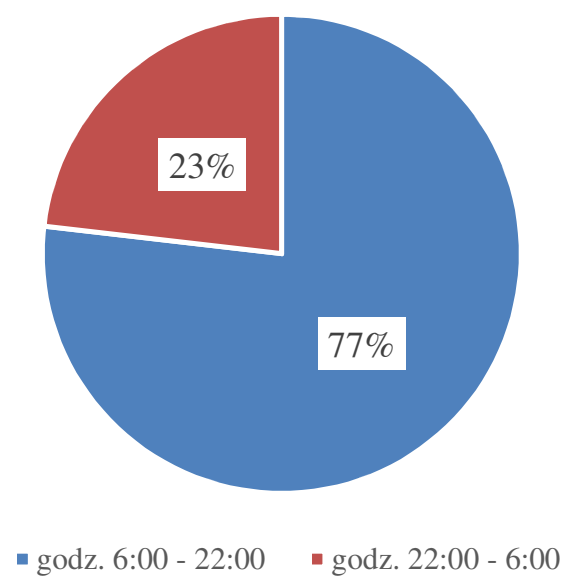

3. Distribution of heavy vehicle traffic per day on national and provincial roads based on data from the General Traffic Measurement in 2015 [5, 6]

Tables 1 and $\mathbf{2}$ show examples of average monthly weighted air temperatures for meteorological stations located in Suwałki and Tarnów, taking into account the daily distribution of heavy vehicle traffic, as well as the monthly average surface temperature values determined on their basis in the years 1989-2019.

Tab. 1. The monthly weighted average air temperature values and the monthly average pavement temperature values in the years 1989 - 2019 for the weather station in Suwałki

\begin{tabular}{|c|c|c|c|c|c|c|c|c|c|c|c|c|}
\hline \multirow{2}{*}{ Suwałki } & \multicolumn{12}{|c|}{ month } \\
\hline & I & II & III & IV & V & VI & VII & VIII & IX & $X$ & XI & XII \\
\hline $\begin{array}{l}\text { Monthly } \\
\text { weighted } \\
\text { average air } \\
\text { temperature } \\
{\left[{ }^{\circ} \mathrm{C}\right]}\end{array}$ & $-3,54$ & $-2,36$ & 1,33 & 8,20 & 12,96 & 16,13 & 18,24 & 17,58 & 12,57 & 7,11 & 2,40 & $-1,63$ \\
\hline $\begin{array}{l}\text { Average } \\
\text { monthly } \\
\text { surface } \\
\text { temperature } \\
{\left[{ }^{\circ} \mathrm{C}\right]}\end{array}$ & $-0,86$ & 0,49 & 4,70 & 12,53 & 17,95 & 21,57 & 23,97 & 23,21 & 17,51 & 11,28 & 5,91 & 1,32 \\
\hline
\end{tabular}


Tab. 2. The monthly weighted average air temperature values and the monthly average pavement temperature values in the years 1989 - 2019 for the meteorological station in

Tarnów

\begin{tabular}{|c|c|c|c|c|c|c|c|c|c|c|c|c|}
\hline \multirow{2}{*}{ Tarnów } & \multicolumn{12}{|c|}{ month } \\
\hline & I & II & III & IV & V & VI & VII & VIII & IX & $\mathrm{X}$ & XI & XII \\
\hline $\begin{array}{l}\text { Monthly } \\
\text { weighted } \\
\text { average air } \\
\text { temperature } \\
{\left[{ }^{\circ} \mathrm{C}\right]}\end{array}$ & $-0,92$ & 0,66 & 4,88 & 10,22 & 14,76 & 18,24 & 19,85 & 19,38 & 14,47 & 9,57 & 5,34 & 1,02 \\
\hline $\begin{array}{l}\text { Average } \\
\text { monthly } \\
\text { surface } \\
\text { temperature } \\
{\left[{ }^{\circ} \mathrm{C}\right]}\end{array}$ & 2,12 & 3,93 & 8,74 & 14,82 & 20,00 & 23,97 & 25,81 & 25,26 & 19,67 & 14,09 & 9,26 & 4,35 \\
\hline
\end{tabular}

\section{Equivalent temperature calculation method}

The method of calculating the equivalent temperature consists of the following steps adopted based on the calculation procedure contained in the book [2]:

1. Selection of meteorological stations in Poland with a complete temperature database for the analyzed period of analysis.

2. Adoption of pavement construction. In these analyzes, the pavement structure was adopted for the KR5 traffic category.

3. Determining the monthly weighted average air temperature for individual locations, taking into account the variability of heavy vehicle traffic during the day.

4. Calculation of the monthly average pavement temperature according to equation (1) for the considered calculation period for each meteorological station separately.

5. Calculation of the fatigue life using the fatigue cracking criterion of asphalt layers according to the AASHTO 2004 method and the criterion of structural deformation of the subsoil according to the Asphalt Institute.

In the calculation of fatigue life using the fatigue cracking criterion of asphalt layers from the AASHTO 2004 method, first with the BANDS 2.0 program. the values of the stiffness moduli of asphalt mixtures for individual asphalt pavement layers were determined in the temperature range from $-20^{\circ} \mathrm{C}$ to $30^{\circ} \mathrm{C}$ with steps of $5^{\circ} \mathrm{C}$. For this purpose, the values of the stiffness moduli of the asphalt binders were calculated: 35/50 (for the asphalt base course and the bonding layer) and 50/70 (for the wearing course). Then, the modulus of stiffness of asphalt mixtures was determined, taking into account in the calculations the values of the volumetric content of voids and asphalt content adopted based on Table 10.4 in the book [2].

In the next stage, the value of the tensile strain at the bottom of the packet of asphalt layers and the vertical deformation on the surface of the subsoil were calculated using the BISAR 3.0 software. These values were determined taking into account the previously calculated values of the stiffness modulus of asphalt mixtures, the assumed value of the modulus of elasticity of the main base from the mixture unbound with the aggregate $C_{90 / 3}(E=400 \mathrm{MPa})$, and the adopted constant value of the modulus of elasticity of the subsoil $\left(E_{0}=120 \mathrm{MPa}\right)$ on the surface of the lower layers of the pavement structure and the layer of improved subsoil.

The next stage of calculations was to determine the fatigue life at each temperature from the previously adopted temperature range. The calculations were carried out using the fatigue cracking criterion of asphalt layers according to the AASHTO 2004 method and the soil 
substrate structural deformation criterion according to the Asphalt Institute criterion, which was also applied during works for the catalog. The fatigue life of asphalt layers, which is the number of repetitive loads until the fatigue cracks appear on the pavement surface, was calculated from the dependence (2) assuming the permissible number of cracks as $15 \%$ of the total lane area. The following relationship was adopted from the article [4] and was reduced from imperial units to metric units.

where:

$$
N_{f}=D_{F C} \cdot 7,3557 \cdot\left(10^{-6}\right) \cdot C \cdot k^{\prime}{ }_{1}\left(\frac{1}{\varepsilon_{t}}\right)^{3,9492}\left(\frac{1}{E}\right)^{1,281}
$$

$N_{f}$ - number of repetitive loads until mesh cracks occur on $15 \%$ of the total lane area [-]; $D_{F C}$ - fatigue damage on the underside of the layers [-]

$$
D_{F C}=10^{\ln \left(\frac{100}{F C_{\text {bottom }}}-1\right) \cdot \frac{1}{C^{\prime}{ }_{2}}-2}
$$

The dependence (3) was obtained from the transformation of the dependence (6.7) described in detail in the book [2] in subsection 6.2.2.5.

$C$ - coefficient depending on the asphalt volume content and voids in the asphalt-mineral mixture [-]:

$$
\begin{gathered}
C=10^{M} \\
M=4,84 \cdot\left(\frac{v_{b}}{v_{a}+v_{b}}-0,69\right)
\end{gathered}
$$

where:

$v_{a}-$ volumetric void content [\%];

$v_{b}-$ volumetric content of asphalt minus the asphalt absorbed in the aggregate pores $[\%]$

$k^{\prime}{ }_{1}$ - parameter determined in the calibration process, depending on the thickness of the asphalt layer and the type of cracks [-]

"Bottom-up" cracks:

where:

$$
k^{\prime}{ }_{1}=\frac{1}{0,000398+\frac{0,003602}{1+e^{\left(11,02-3,49 \cdot h_{a c}\right)}}}
$$

$h_{a c}-$ total thickness of all asphalt layers [inches];

$\varepsilon_{t}-$ tensile deformation at the bottom of the asphalt layers of the adopted pavement structure $[-]$

$E-$ stiffness modulus of the asphalt layer [MPa];

The fatigue life due to the structural deformation of the subsoil was calculated based on the criterion of the Asphalt Institute:

where:

$$
N_{f, p}=\left(\frac{\varepsilon_{z z}}{1,05 \cdot 10^{-2}}\right)^{-\frac{1}{0,223}}
$$

$N_{f, p}$ - the number of permissible standard axle loads until the occurrence of critical permanent deformations of the subsoil [-];

$\varepsilon_{z z}-$ deformation on the upper surface of the subsoil [-];

\section{Determination of the polynomial function determining the relation between fatigue life and pavement temperature.}

Based on the values obtained from the dependencies (2) and (7), the lower value of the two criteria for a given design temperature was adopted as the resulting fatigue life. The criterion of fatigue cracks in asphalt layers was the main decisive factor. The lower value of the fatigue life obtained from the structural deformation criterion was obtained only for the pavement 
temperatures of $+25^{\circ} \mathrm{C}$ and $+30^{\circ} \mathrm{C}$. The dependence of the calculated fatigue life values on the pavement temperature was described by the polynomial function of the fourth degree $\mathrm{N}$ (T), which is shown in Figure 4.

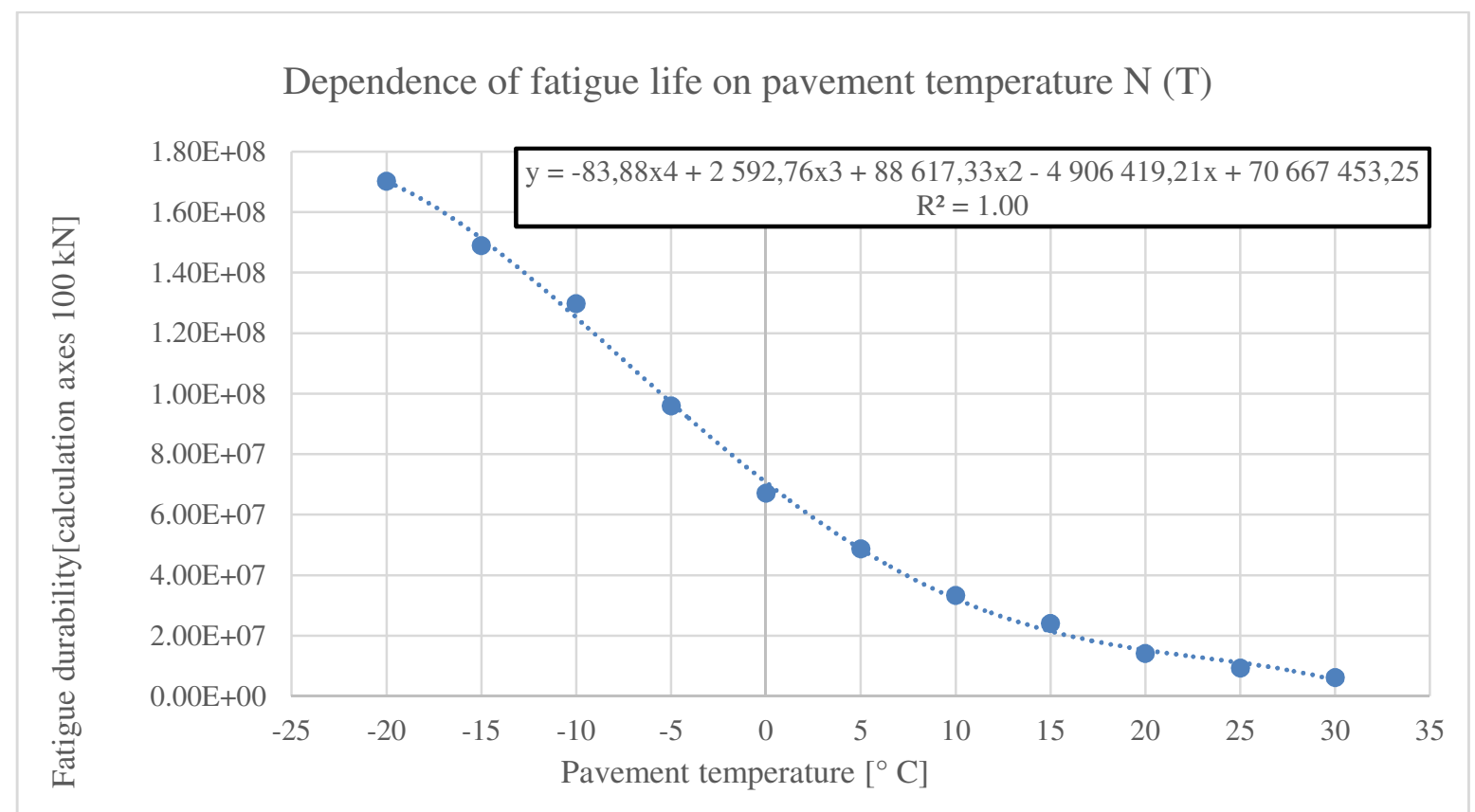

4. Dependence of fatigue life on pavement temperature $\mathrm{N}(\mathrm{T})$ in the temperature range from $20^{\circ} \mathrm{C}$ to $30^{\circ} \mathrm{C}$ for pavement structure for the KR5 traffic category

7. Determining the fatigue life for a given month.

Using the obtained dependence of the fatigue life on the pavement temperature described by the polynomial function of the fourth degree and based on the average monthly pavement temperature for 30 years, the value of the fatigue life in a given month was calculated for each location of the meteorological station separately.

\section{Calculation of the annual fatigue life.}

Based on the dependence (8), the annual fatigue life was calculated for each of the adopted locations. This value takes into account the variable distribution of traffic throughout the year, adopted based on the assumptions described in the book [2]. The highest traffic load was assumed for the summer months: June, July, August (the percentage share of traffic for each month of the year is $10 \%$ ), the lowest for the winter period: December, January, February $(6.67 \%)$, and the average traffic load in months: March, April, May, September, October, November $(8.33 \%)$.

where:

$$
N_{\text {rok }}=\frac{100}{\left(\frac{\% r u c h_{1}}{N_{1}}+\frac{\% r u c h_{2}}{N_{2}}+(\ldots)+\frac{\% r u c h_{12}}{N_{12}}\right)}
$$

$N_{\text {rok }}$ - fatigue life of pavement structures throughout the year [-],

$\% \mathrm{ruch}_{n}$ - the percentage share of traffic in relation to the entire year in a given month [\%],

$N_{n}$ - fatigue life calculated in a given month from the dependence $\mathrm{N}(\mathrm{T}),[-]$,

$n$ - month number [2].

9. Calculation of the equivalent temperature value.

Using the calculated values of the annual fatigue life obtained from the relationship (8), the fourth-degree polynomial was solved for each location of the meteorological station. In this 
way, the value of the equivalent temperature was obtained, at which the fatigue damage in the analyzed pavement is equal to the sum of fatigue damage that occurs at different temperatures throughout the year.

The results of the equivalent temperature calculations for the assumed locations of meteorological stations and their analysis

As a result of the performed calculations, 50 values of the equivalent temperature were obtained, depending on the air temperatures at a given location of the meteorological station. The obtained results are presented graphically in Figure 5. As in the case of the analysis of average air temperature values, the distribution of isolines was developed in a graphic program using linear interpolation, taking into account the temperature difference between adjacent locations of meteorological stations and the distance between them.

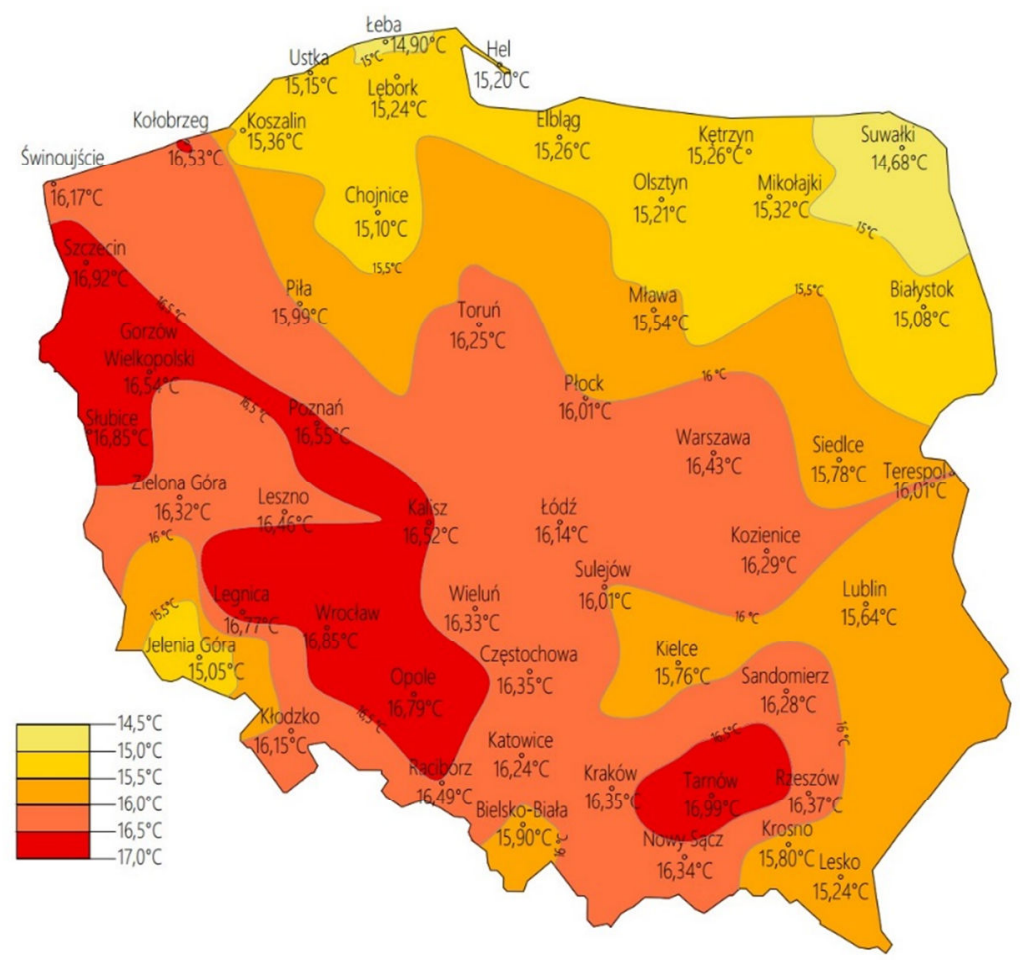

5. Equivalent temperature to the design of the pavement for the adopted meteorological stations in Poland

It is worth noting that the distribution of the equivalent temperature value coincides with the soil freezing zones in Poland. The lowest value of the equivalent temperature was obtained at the meteorological station located in Suwałki $\left(+14.68^{\circ} \mathrm{C}\right)$, and the highest in Tarnów $\left(+16.99^{\circ} \mathrm{C}\right)$. The difference between the extreme values is $2.31^{\circ} \mathrm{C}$ and this translates into the thickness of the designed asphalt layers of pavement structures, which is described later in this article. In order to determine one value of the equivalent temperature for the entire territory of Poland, similarly to the works for the catalog [9], the weighted average value of the equivalent temperature was used, where the weight was the percentage of the territory of Poland with a specific depth of soil freezing:

- $0,8 \mathrm{~m}$ - area of $29.5 \%$ of the territory,

- $1,0 \mathrm{~m}$ - area of $57,1 \%$ of the territory,

- $1,2 \mathrm{~m}$ - area of $10,9 \%$ of the territory,

- $1,4 \mathrm{~m}-\mathrm{o}$ area of $2,5 \%$ of the territory. 
The list of the determined values of the equivalent temperatures grouped depending on the freezing zone of the ground and the weighted average value of the equivalent temperature for Poland is presented in Table 3 .

Tab. 3. Summary of the determined values of the equivalent temperatures and the weighted average value of the equivalent temperature for Poland

\begin{tabular}{|c|c|c|}
\hline $\begin{array}{l}\text { Percentage of the } \\
\text { territory of Poland with a } \\
\text { given frost depth }\end{array}$ & $\begin{array}{l}\text { Location of the } \\
\text { meteorological station }\end{array}$ & $\begin{array}{l}\text { Equivalent temperature for } \\
\text { traffic category KR5 }\left[{ }^{\circ} \mathrm{C}\right]\end{array}$ \\
\hline \multirow{13}{*}{$29,5 \%(0,8 \mathrm{~m})$} & Chojnice & 15,10 \\
\hline & Słubice & 16,85 \\
\hline & Szczecin & 16,92 \\
\hline & Poznań & 16,55 \\
\hline & Leszno & 16,46 \\
\hline & Legnica & 16,77 \\
\hline & Kalisz & 16,52 \\
\hline & Kłodzko & 15,16 \\
\hline & Gorzów Wielkopolski & 16,45 \\
\hline & Jelenia Góra & 15,05 \\
\hline & Koszalin & 15,36 \\
\hline & Wrocław & 16,85 \\
\hline & Zielona Góra & 16,32 \\
\hline & Piła & 15,99 \\
\hline & Świnoujście & 16,17 \\
\hline & Ustka & 15,15 \\
\hline & Kołobrzeg & 16,53 \\
\hline \multirow{19}{*}{$57,1 \%(1,0 \mathrm{~m})$} & Rzeszów & 16,37 \\
\hline & Sandomierz & 16,28 \\
\hline & Olsztyn & 15,21 \\
\hline & Opole & 16,79 \\
\hline & Płock & 16,01 \\
\hline & Mława & 15,54 \\
\hline & Łódź & 16,14 \\
\hline & Częstochowa & 16,35 \\
\hline & Lublin & 15,64 \\
\hline & Kraków & 16,35 \\
\hline & Bielsko-Biała & 15,90 \\
\hline & Terespol & 16,01 \\
\hline & Racibórz & 16,49 \\
\hline & Łeba & 14,90 \\
\hline & Tarnów & 16,99 \\
\hline & Siedlce & 15,78 \\
\hline & Sulejów & 16,01 \\
\hline & Elbląg & 15,26 \\
\hline & Katowice & 16,24 \\
\hline
\end{tabular}




\begin{tabular}{|c|l|c|} 
& Kielce & 15,76 \\
\cline { 2 - 3 } & Kozienice & 16,29 \\
\cline { 2 - 3 } & Lębork & 15,24 \\
\cline { 2 - 3 } & Wieluń & 16,33 \\
\cline { 2 - 3 } & Hel & 15,20 \\
\cline { 2 - 3 } & Toruń & 16,25 \\
\cline { 2 - 3 } & Warszawa & 16,43 \\
\hline \multirow{3}{*}{$10,9 \%(1,2 \mathrm{~m})$} & Mikołajki & 15,32 \\
\cline { 2 - 3 } & Lesko & 15,24 \\
\cline { 2 - 3 } & Nowy Sącz & 16,34 \\
\cline { 2 - 3 } & Kętrzyn & 15,23 \\
\cline { 2 - 3 } & Krosno & 15,80 \\
\cline { 2 - 3 } & Białystok & 15,08 \\
\hline \multirow{2}{*}{$2,5 \%(1,4 \mathrm{~m})$} & Suwałki & 14,68 \\
\hline \multirow{2}{*}{ Weighted mean value of the equivalent temperature for } & \\
\hline & Poland & 16,01 \\
\hline
\end{tabular}

The weighted mean value of the equivalent temperature for Poland, rounded to whole degrees, is $16^{\circ} \mathrm{C}$ and is higher than the equivalent temperature adopted in the catalog [9] by $3^{\circ} \mathrm{C}$. To better illustrate the definition of the equivalent temperature, it is worth noting that it should not be confused with the average air temperature during the year. These values differ significantly from each other, which can be seen when comparing Figures $\mathbf{1}$ and $\mathbf{5}$.

\section{Analysis of the impact of the equivalent temperature change on the designed thickness of asphalt pavement layers}

The equivalent temperature, which is directly related to the fatigue life of the pavement structure, is required for the design of the thickness of the asphalt pavement layers. In these analyzes of the impact of the equivalent temperature change on the thickness of the asphalt layer pack, a variable thickness of the asphalt base layer was assumed. Figure $\mathbf{6}$ shows the results of fatigue life calculations for the analyzed asphalt layer thicknesses at variable values of the equivalent temperature. The figure also shows the value of the equivalent temperature $\left(+13^{\circ} \mathrm{C}\right)$ adopted in the catalog [9], which ensures the required fatigue life of the asphalt pavement for the KR5 traffic category.

As a result of the performed calculations of the equivalent temperature values, it can be concluded that, depending on the location, the thickness of the asphalt pavement layers in Poland may be in the range from $24 \mathrm{~cm}$ (Suwałki $+14.68^{\circ} \mathrm{C}$, rounded $+15^{\circ} \mathrm{C}$ ) to $25 \mathrm{~cm}$ (Tarnów $+16.99^{\circ} \mathrm{C}$, rounded $+17^{\circ} \mathrm{C}$ ). This means a difference in the thickness of the asphalt layers of $1 \mathrm{~cm}$. However, after taking into account the working tolerances, the equal value of the thickness of the asphalt layers $(25 \mathrm{~cm})$ can be assumed, which justifies the determination of one equivalent temperature value for the entire territory of Poland with the adopted distribution of values as shown in Figure 5. A further increase in the average air temperature values in Poland and the world may cause a significant increase in the value of equivalent temperatures and, consequently, the need to increase the designed thickness of asphalt layers. The analyzes show that for the temperature equivalent to $+13^{\circ} \mathrm{C}$ currently in force in the catalog [9], the thickness of the asphalt layers without taking into account the construction tolerances (additional $1 \mathrm{~cm}$ ), which meets the required fatigue life of the pavement structure for $\mathrm{KR} 5$, is $23 \mathrm{~cm}$. Referring to the weighted average value of the equivalent temperature for Poland $\left(+16^{\circ} \mathrm{C}\right)$ determined in this article, the thickness of the asphalt layers should be 25 
$\mathrm{cm}$. This shows a difference of $2 \mathrm{~cm}$, which suggests the need to update the temperature equivalent to the design of the pavement structure over the years. It is also worth noting that with the increase of the equivalent temperature, the fatigue life of the pavement decreases.

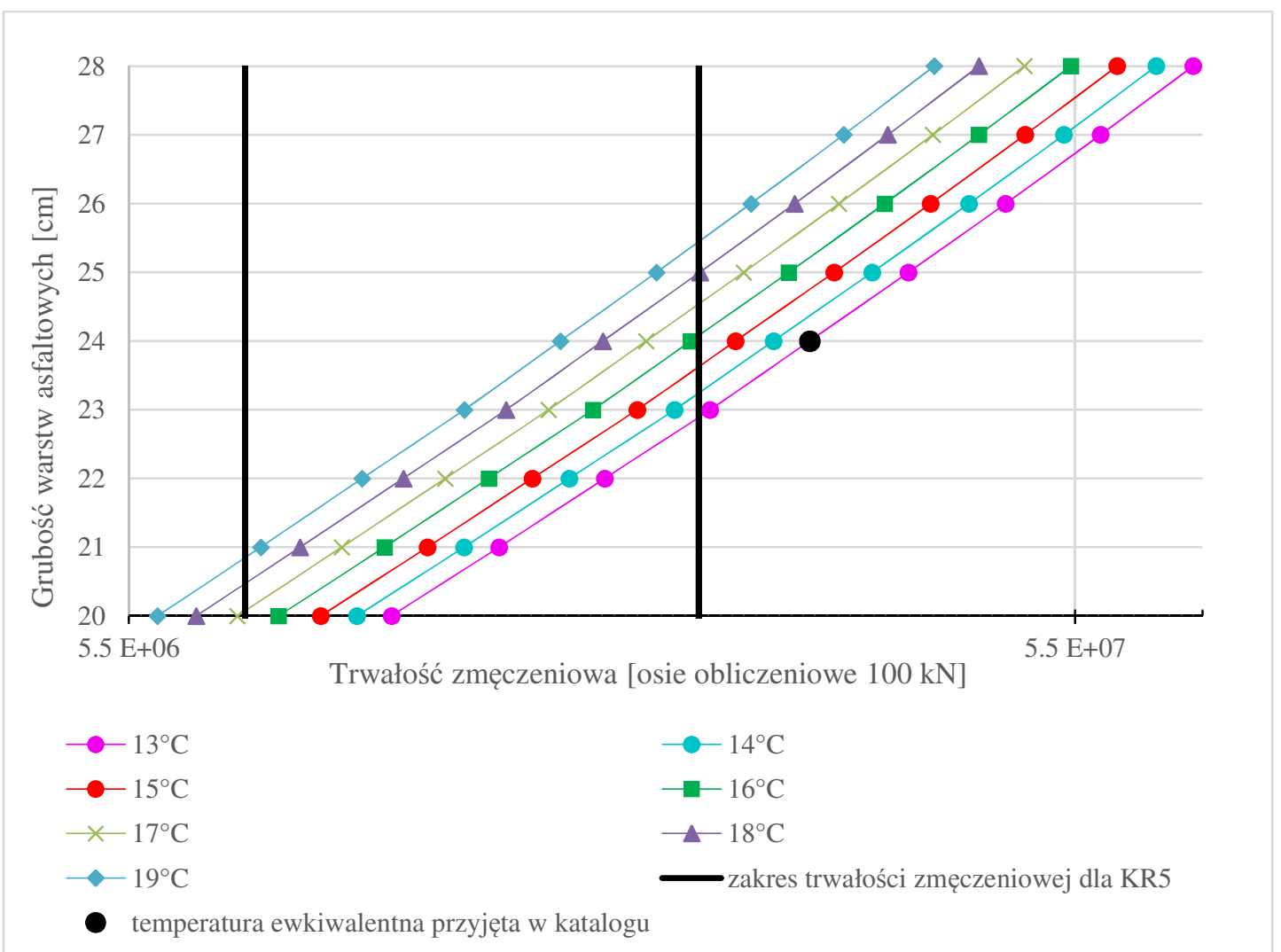

6. Dependence of asphalt layer thickness on fatigue life at a variable equivalent temperature to the KR5 pavement structure

\section{Summary and Conclusions}

The equivalent temperature to the design of road pavement structures changes with the change of air temperature. It is important for the design of the pavement structure because it is defined as a constant temperature value at which the fatigue damage that the pavement would undergo at this temperature is equal to the sum of fatigue damage that occurs during the year under changing temperature conditions under the assumed traffic load. Therefore, this value should be regularly updated based on the latest temperature data available.

This article analyzes the temperature equivalent to the design of asphalt pavements in Poland based on the latest available temperature data from 1989 to 2019 inclusive. The distribution of average annual air temperatures obtained from the available 30-year data coincides with the current soil freezing zones in Poland.

The computational analyzes have shown that the value of the equivalent temperature is variable in Poland. The extreme values of equivalent temperatures obtained from calculations (Suwałki $+14.68^{\circ} \mathrm{C}$ and Tarnów $+16.99^{\circ} \mathrm{C}$ ) determined based on fatigue criteria differ by $2.31^{\circ} \mathrm{C}$ depending on the location of the meteorological station. This justifies the possibility of adopting one equivalent temperature value for the entire territory of Poland.

The determined average weighted value of the equivalent temperature for Poland, where the weight is the percentage of the territory of Poland with a specific depth of soil freezing, is $+16^{\circ} \mathrm{C}$. This means the possibility of designing the thickness of asphalt layers equal to $25 \mathrm{~cm}$ throughout Poland for the analyzed traffic category KR5 and taking into account the implementation tolerances. 
The analysis of the weighted average temperature equivalent for Poland $\left(+16^{\circ} \mathrm{C}\right)$ determined based on the latest temperature data and the current value in the catalog [9] (+ $13^{\circ} \mathrm{C}$ ) indicates the need to increase the thickness of the asphalt layers of pavement structures for the KR5 traffic category by $2 \mathrm{~cm}$, disregarding the manufacturing tolerances. A further increase in the average air temperature values in Poland and the world may cause a significant increase in the values of equivalent temperatures and, consequently, the need to increase the designed thickness of asphalt layers.

The equivalent temperature values determined in this article should not be directly compared with the value adopted in the catalog [9], because they were calculated based on temperature data from another period and various criteria and assumptions were used to determine them.

This article was written as part of a research and teaching project entitled "Szkoła Ortów" implemented under the Operational Program: Knowledge, Education, Development, cofinanced by the European Social Fund POWR.03.01.00-00-P015/18 and announced by the Ministry of Science and Higher Education.

\section{Acknowledgments}

The authors would like to thank the Institute of Meteorology and Water Management for providing temperature data from meteorological stations in Poland.

I would also like to thank the Ministry of Science and Higher Education for the opportunity to participate in the research and teaching project entitled "Szkoła Orłów".

\section{Source materials}

[1] Guide for Mechanistic-Empirical Design of New and Rehabilitated Pavement Structures. Final Report, Part 3 - Design and Analysis, NCHRP, TRB, NRC, March 2004.

[2] Judycki J. i inni. Analizy i projektowanie konstrukcji nawierzchni podatnych i półsztywnych. Wydawnictwa Komunikacji i Łączności, 2014.

[3] Judycki J. Modele spękań zmęczeniowych warstw asfaltowych nawierzchni drogowych w mechanistyczno-empirycznej metodzie AASHTO 2004. Drogownictwo, 2011, nr 11, str. 343-347.

[4] Judycki J. Budowa i kalibracja modeli spękań zmęczeniowych warstw asfaltowych nawierzchni drogowych w mechanistyczno-empirycznej metodzie AASHTO 2004, Roads and Bridges - Drogi i Mosty, 2011, Nr 4, str. 31-53.

[5] Opoczyński K. Podsumowanie wyników GPR 2015 na zamiejskiej sieci dróg wojewódzkich. Generalna Dyrekcja Dróg Krajowych i Autostrad, 2016.

[6] Opoczyński K. Synteza wyników GPR 2015 na zamiejskiej sieci dróg krajowych. Generalna Dyrekcja Dróg Krajowych i Autostrad, 2016.

[7] Spławińska M., Zieliński P. Wpływ natężenia ruchu pojazdów ciężkich na trwałość konstrukcji nawierzchni drogowej. Drogownictwo, 2015, nr 3, str. 98-104.

[8] Sybilski D., Bańkowski W. Temperatura równoważna nawierzchni asfaltowej ze względu na zmęczenie w polskich warunkach klimatycznych. Drogownictwo, 2004, nr 6, str. 179184.

[9] Załącznik do zarządzenia Nr 31 Generalnego Dyrektora Dróg Krajowych i Autostrad z dnia 16.06.2014r. Katalog Typowych Konstrukcji Nawierzchni Podatnych i Półsztywnych. 